\title{
Editorial
}

\section{The jobs crisis: causes, cures, constraints}

As last year, the second issue of the European Journal of Economics and Economic Policies: Intervention (EJEEP) in 2014 is devoted to the Papers and Proceedings of the Research Network Macroeconomics and Macroeconomic Policies (FMM). The 17th annual FMM conference on 'The jobs crisis: causes, cures, constraints' took place in Berlin on 24-26 October 2013.

At the time of writing, and more than 6 years after the beginning of the financial crisis in the United States, the world economy is still highly fragile. In particular, many countries are facing a severe jobs crisis. This is especially true for the euro area, which suffered a double-dip recession in 2012 and 2013 and where unemployment has reached unprecedented levels, particularly in the south. Especially worrying is the surge in youth unemployment in some countries. Even in those parts of the world where unemployment is comparatively low, a jobs crisis of a different nature frequently exists: many jobs are precarious and low-paid or otherwise of poor quality.

Some of the questions discussed at last year's FMM conference were the following: Where are new and decent jobs to come from? What is the scope of macroeconomic policy to reduce unemployment? What is the role of labour market institutions and policies in the current context? And, in the face of environmental concerns, how can employment be decoupled from economic growth and green jobs promoted? The contributions to this issue of the journal were all made at the three plenary sessions during the conference. ${ }^{1}$

The first contribution to this special issue is by Rod Cross and is entitled 'Unemployment: natural rate epicycles or hysteresis?'. The author argues that the natural rate of unemployment hypothesis, in which equilibrium unemployment is determined by 'structural' variables alone, is both implausible and inconsistent with the evidence. Instead, equilibrium unemployment is haunted by hysteresis. The history of the natural rate hypothesis is curious not least because the authors of the hypothesis thought hysteresis to be relevant. The various methods that have been used to model hysteresis in economic systems are outlined, including the Preisach model with its selective, erasable memory properties. The evidence on the importance of hysteresis effects on output and unemployment is then reviewed.

Laurence Ball then specifically addresses the 'Long-term damage from the Great Recession in OECD countries', providing estimates of the long-term impact of the global recession of 2008-2009 on output by comparing current estimates of potential output to the path that potential was following in 2007 , according to estimates at the time. The average loss, weighted by economy size, is very substantial, at 8.4 per cent. Most countries have experienced strong hysteresis effects: shortfalls of actual output from pre-recession trends have reduced potential output almost one-for-one. Moreover, in the hardest-hit

1. Videos of the presentations can be found at: https://www.youtube.com/playlist?list=PLRIUZP0fg52bXsI-tnQY0HLOdMxrpgQ8/. A substantial number of the papers given at workshops during the conference can be downloaded from: http://www.boeckler.de/35327_44396.htm/. 
economies, the current growth rate of potential is also depressed, implying that the extent of lost potential is growing over time.

In his contribution, 'Restructuring finance to promote productive employment', Gerald Epstein argues that while modern financial markets and institutions have expanded massively in relation to the economy in the United States and elsewhere, there is little evidence that their contributions to economic output and social welfare justify the resources they capture and the economic and also the political risks they impose on society. He concludes that abandoning the decades-long embrace of speculative finance and instead promoting socially efficient finance is a key imperative facing the United States and many other countries who adopted financial liberalisation in the late twentieth century.

Sigrid Stagl, in her article 'Ecological macroeconomics: reflections on labour markets', outlines the elements of an ecological macroeconomics and draws out some implications for labour markets. She discusses reasons for growth constraints and options for measuring the biophysical basis of economic production. Stagl then goes on to explore implications for labour markets and for environmental and social policies. Specifically, she explores emerging building blocks for an ecological macroeconomics and aims to support further development of ecological macroeconomic modelling by (1) discussing biophysical accounting options and experiences in using them; and (2) the crucial role of labour market performance and rethinking labour market institutions for achieving higher environmental sustainability.

Engelbert Stockhammer, Alexander Guschanski and Karsten Köhler explore the links between 'Unemployment, capital accumulation and labour market institutions in the Great Recession'. Their contribution restates the post-Keynesian view of unemployment within a NAIRU (non-accelerating inflation rate of unemployment) framework. According to the authors, capital investment rather than labour market institutions is the crucial variable that explains changes in unemployment performance. They provide econometric evidence that the post-Keynesian view holds up well in the recession following the crisis of 2008.

The two concluding articles, by Dean Baker and Joachim Möller, analyse the US and German labour markets, respectively, in the aftermath of the recent financial and economic crisis. Dean Baker analyses 'The enduring effects of the Great Recession on wage growth in the United States'. Baker notes that workers in the United States have fared notably worse than workers in other wealthy countries over the last 3 decades. During most of this period, wages for the median worker have barely kept pace with inflation. As bad as the situation had been prior to the Great Recession, it has sharply deteriorated in the 6 years since the downturn began. There is a real risk that workers could face a decade of widespread unemployment and underemployment, with wages at best keeping pace with inflation in the absence of effective counteraction by macroeconomic policies.

Focusing on the case of Germany, Joachim Möller asks: 'In the aftermath of the German labor market reforms, is there a qualitative/quantitative trade-off?'. The article argues that the German labour market reforms implemented in 2003-2005 were largely successful, according to the main quantitative and also some qualitative indicators of labour market conditions. On the negative side, however, the wage growth for many groups of workers is unsatisfactory, as are other qualitative elements. Möller argues that this was not a necessary condition for the improvement of the employment rate 
but was instead an unintended by-product of the reforms. Therefore, this side effect can be corrected without jeopardising the reforms' indisputable successes in terms of the employment rate.

Özlem Onaran Greenwich University, London, UK

Miriam Rehm Austrian Federal Chamber of Labour, Vienna, Austria

Till van Treeck University of Duisburg-Essen, Germany

Andrew Watt Macroeconomic Policy Institute, Hans Böckler Foundation, Düsseldorf, Germany 